University of New Orleans

ScholarWorks@UNO

$12-1983$

\title{
Literary Nationalism and Ambivalence in Washington Irving's The Life and Voyages of Christopher Columbus
}

John D. Hazlett

University of New Orleans, jhazlett@uno.edu

Follow this and additional works at: https://scholarworks.uno.edu/engl_facpubs

Part of the Literature in English, North America Commons

\section{Recommended Citation}

Hazlett, John D. "Literary Nationalism and Ambivalence in Washington Irving's The Life and Voyages of Christopher Columbus." American Literature: A Journal of Literary History, Criticism, and Bibliography 55.4 (1983): 560-575.

This Article is brought to you for free and open access by the Department of English and Foreign Languages at ScholarWorks@UNO. It has been accepted for inclusion in English Faculty Publications by an authorized administrator of ScholarWorks@UNO. For more information, please contact scholarworks@uno.edu. 


\title{
Literary Nationalism and Ambivalence in Washington Irving's
}

The Life and Voyages of Christopher Columbus

\author{
JOHN D. HAZLETT \\ University of Iowa
}

\section{W'ashington Irving's The Life and Voyages of Christopher W Columbus had its genesis in the historic dilemma whose struc-} ture is familiar to students of American literature. At the beginning of the nineteenth century, American writers plotted a rebellion against the dependence of American letters on European, and especially English, models. ${ }^{1}$ What was needed, they claimed, was a declaration of literary independence, the creation of a national literature making use of American materials and American themes. Their dependence upon English literary models was so deep, however, that there was much confusion about the precise form an "original" literature should take. In order to help solve the problem, writers in a number of prominent journals set about drawing up a list of topics that ought to be dealt with in a truly American literature.

The call for an indigenous literature, however, was not without its critics. Many writers felt that there was no American language, and that as long as American writers were dependent upon a foreign tongue as the very basis of their literature, there could be no writing that was thoroughly native. Furthermore, according to a fashionable theory derived from associationist psychology, the language of literature could not be imaginatively affective unless its subjects were connected in the minds of readers with inherited feelings and established associations. The theory left American writers paralyzed; America as a "new" country had no established associations because its native scenes, historical events, and legendary heroes had never

\footnotetext{
${ }^{1}$ For a detailed discussion of this issue, see Benjamin T. Spencer, The Quest for Nationality: An American Literary Campaign (Syracuse: Syracuse Univ. Press, 1957), pp. 25-72, 195-218.
}

American Literature, Volume 55, Number 4, December 1983. Copyright (C) 1983 by the Duke University Press. 
been written about. But, paradoxically, such scenes, events and heroes could not be written about because there were no established associations on which to base the writing. ${ }^{2}$

Irving had participated, early in his career, in the nationalist debate by lamenting the impossibility of a native literature in a country without historical associations. In a well-known passage from the Sketch Book, he announced that the lack of an appropriate cultural landscape was the reason behind his removal to Europe which "held forth the charms of storied and poetical associations. There were to be seen the masterpieces of art, the refinements of highly cultivated society, the quaint peculiarities of ancient and local custom. My native country was full of youthful promise: Europe was rich in the accumulated treasures of age. Her very ruins told the history of times gone by, and every mouldering stone was a chronicle." 3

Many years later, Irving changed his mind and returned from Europe, but before doing so, he produced The Life and Voyages of Christopher Columbus, a two volume work which dealt with what he finally came to see as America's rich past. At the time he was composing this ostensibly non-fictional work, he was laboring under accusations that he had betrayed America by living for so long in Europe. In a letter to a friend in New York, he complained of these attacks and insisted that "all the colouring that the imagination once gave to distant Europe now gathers about the scenes of my native country. I look forward to my return as to the only event of any discernible kind that may yet be in store for me."

Irving seems to have thought that this new biography would mollify his critics by making an important contribution to the development of an authentically American literature. By "creating" an American history, he was building up a fund of associations and feelings about the physical and intellectual landscape of America. In his preface to the work, he wrote: "I perceived that, although there

2 William Charvat, The Origins of American Critical Thought: 1810-1835 (Philadelphia: Univ. of Pennsylvania Press, 1936), pp. 141-43. See also Walter Channing's "Essay on American Language and Literature" (1815), reprinted in Reality \& Myth in American Literature, ed. Kay S. House (New York: Fawcett, 1966), pp. I I I-15.

3 "The Author's Account of Himself," The Sketch Book (London: John Miller, 1820), I, 5-6.

${ }^{4}$ Letters of Washington Irving to Henry Brevoort, ed. George S. Hellman (New York: Putnam, 1918), p. 409. 
were many books, in many languages, relative to Columbus, they all contained limited and incomplete accounts of his life and voyages; while numerous valuable tracts on the subject existed only in manuscript or in the form of letters, journals, and public muniments. It appeared to me that a history, faithfully digested from these various materials, was a desideratum in literature . . . and a more acceptable work to my country, than the translation I had contemplated." ${ }^{\prime 5}$ The book, which he intended as an offering to his country, was to be distilled from "every document relative to the early history of America" $(I, 10)$; it was to be an attempt to fulfill one of the desiderata of American literature: the creation of an American hero.

The need for legendary figures was already being partially met by the frequent appearance in literary journals of essays dealing with eminent figures in American history. The patriotic tone of most of these essays reveals the mythic status granted to the American past. Few of these essayists ever stopped to consider that such an attitude toward the past might affect their regard for accuracy. One writer, for example, emphatically and typically stated that "to the sanctity of American history, all other considerations must yield." The same writer, who presented the history of Colonel Isaac Hayne during the Revolutionary War, concluded his essay: "We have now performed ... what we consider a duty to the memory of one of the most revered of our martyrs. It is due to the country, that not a single trophy of the Revolution should be suffered to be destroyed. . . . We would . . . preserve them all . . . to kindle in the bosom of our American youth . . . the sacred glow of patriotism." In a similar spirit, Irving wrote in his biography of Columbus: "There is a certain meddlesome spirit, which, in the garb of learned research, goes prying about the traces of history, casting down its monuments, and marring and mutilating its fairest trophies. Care should be taken to vindicate great names from such pernicious erudition. It defeats one of the most salutary purposes of history, that of furnishing examples of what human genius and laudable enterprise may accomplish" $(I, 56)$. Irving, like the author of the Hayne essay, saw American

${ }^{5}$ The Life and Voyages of Christopher Columbus (New York: Putnam, 1861), I, 10, hereafter referred to as Columbus. All further references to this two-volume work, originally published in 1828 , will be noted in the body of the essay.

${ }^{6}$ Anon., "A History of a Campaign of the Revolution," Southern Review, I (Jan. 1828), 75, 105. 
history as a useful means of instilling patriotism in his readers, and while his language tended to be more general, his avowed intention toward Columbus was thoroughly nationalist. The trophy he was saving from mutilation was, after all, the discoverer of the Americas, upon whose character the glory and pride of the New World in some measure depended.

Side by side with his espousal of literary nationalism, however, Irving voiced another biographical intention: "In the execution of this work $I$ have avoided indulging in mere speculations or general reflections, excepting such as rose naturally out of the subject, preferring to give a minute and circumstantial narrative, omitting no particular that appeared characteristic of the persons, the events, or the times; and endeavoring to place every fact in such a point of view, that the reader might perceive its merits, and draw his own maxims and conclusions" (I, I2-I3). The idea that history and biography ought to provide the reader with an unmediated version of events and personalities is difficult to reconcile with the idea that history should provide "examples of what human genius and laudable enterprise may accomplish." How, we might wonder, was Irving going to create a legend, a cultural hero, without induling in "speculations" and "general reflections"? Clearly, neither of his intentions could be fully borne out in the text, but the fact that each of them was stated in such explicit and simple language, with no apparent awareness of their incompatibility, reveals the naivete with which Irving approached biography. ${ }^{7} \mathrm{Had}$ Columbus' colonial enterprise in the New World been less sanguinary, this naiveté might not have seriously complicated the book. But since European colonialism in the Americas was so bloody, and since Irving was not quite equal to the patriotic task of ignoring this fact, his naiveté about the function of historical writing was further compounded by ambivalence about his subject. It is this ambivalence finally which pervades the tone and vision of the book and which lends it its particular interest.

Most of Irving's critics are offended by his avowed nationalism and fail to see the ambivalence in his portrait of Columbus. Justin Winsor in his competing biography says that Irving's "purpose was to create

${ }^{7}$ William L. Hedges, in "Irving's Columbus: The Problem of Romantic Biography," The Americas, 13 (Oct. 1956), 129, argues: "To a large extent [Irving] may have been unconscious of his approach to history. And consciously he could not formulate his intentions except in stock phrases." 
a hero. He glorified what was heroic, palliated what was unheroic, and minimized the doubtful aspects of Columbus' character. . . . The genuine Columbus evaporates under the warmth of the writer's genius, and we have nothing left but a refinement of clay." ${ }^{8}$ Most of the critics who react this way, however, attack the work with counterevidence that is already present in Irving's text. The problem with the biography, therefore, is not that Irving presented only a partial portrait but rather that, in his ambivalence about the character of his hero and the imperialism that established the American colonies, as well as in his confusion about the function of historical writing, he created two portraits of Columbus. On the one hand, he wished to meet the demands of literary nationalism and so created a Columbus who was "practical and poetical" (II, 5I 6), "noble and lofty" (II, 519), possessed of "natural benignity" (II, 52I), "devoutly pious" (II, 522), and finally a "visionary" (I, 286) who transcended the limitations of his age and the superficial goals of wealth and power that were the incentives for most of his companions. On the other hand, Irving provided evidence for a darker Columbus, one who emerges inevitably out of an anti-imperialism which finally comes to dominate the book. In this sub-text, European civilization and the white man are portrayed as a growing disease that corrupts and infects everything it touches, and Columbus, as the deluded representative of such forces, is responsible for the fall of the New World. It is true, of course, that the nationalist portrait is given rhetorical precedence over this implied darker Columbus, but it is impossible to finish the biography without being overwhelmed by the spectre of genocide upon which the establishment of European "civilization" in the Western world depended, as well as by the more "doubtful aspects" of the hero's character.

Irving depicted the land to which Columbus brought European civilization as an earthly paradise. The natives "seemed almost as if they were existing in the state of primeval innocence of our first parents, before their fall brought sin into the world" ( $I, 229)$ :

[they] existed in that state of primitive and savage simplicity, which some philosophers have fondly pictured as the most enviable on earth; sur-

8 Justin Winsor, Christopher Columbus (Boston: Houghton Mifflin, 1892), p. 60. See also: Anon., "Review of The Life and Voyages of Christopher Columbus," Athenaeum, 9 (22 Feb. 1828), 132. 
rounded by natural blessings, without even a knowledge of artificial wants. ... Hospitality, we are told, was with them a law of nature universally observed. . . Every house was as open to the stranger as his own ... 'mine and thine,' the seeds of all mischief, have no place with them. . . . They seem to live in the golden world, without toil, living in open gardens; not intrenched with dykes, divided with hedges, or defended with walls. They deal truly one with another, without laws, without books, and without judges. They take him for an evil and mischievous man, who taketh pleasure in doing hurt to another. (I, 2IO-II)

Into this Eden, Columbus introduced the white men who brought about its eventual destruction. Irving repeatedly juxtaposes the poignant beauty of the paradise against its fate at the hands of the Spaniards: "[Hispaniola] rose before them in all the splendor of tropical vegetation, one of the most beautiful islands in the world, and doomed to be one of the most unfortunate" (I, 206). The islanders themselves gave their assistance to Columbus in the building of the first fortress at La Navidad, "little dreaming that they were assisting to place on their necks the galling yoke of perpetual and toilsome slavery" $(1,232)$. And finally, in a statement in which the deprecatory references to the natives' ignorance and indolence are overwhelmed by the vision of their impending fate, Irving anticipates his later, more graphic description of imperialistic rapacity: "We cannot help pausing to cast back a look of mingled pity and admiration over this beautiful but devoted region. The dream of natural liberty, of ignorant content, and loitering idleness, was as yet unbroken, but the fiat had gone forth; the white man had penetrated into the land; avarice, and pride, and ambition, and pining care, and sordid labor, and withering poverty, were soon to follow, and the indolent paradise of the Indian was about to disappear forever" (I, 40I).

In passages such as these, Irving's ambivalence about the European voyages of exploration-and, in fact, about the values of European civilization-begins to surface. This is the primary theme of the antiimperialist sub-text: civilization itself is evil; Columbus, as the bringer of civilization to the Americas, is the representative of that evil. In the nationalist text, however, civilization is given conventional eulogistic status, and Columbus is praised, if not for bringing civilization to America, then at least for bringing a vision of civilization: "[Columbus'] conduct was characterized by the grandeur of his 
views, and the magnanimity of this spirit. Instead of scouring the newly-found countries . . . he was desirous of colonizing and cultivating them; of conciliating and civilizing the natives; of building cities; introducing the useful arts; subjecting every thing to the control of law, order, and religion; and thus of founding regular and prosperous empires. In this glorious plan he was constantly defeated by the dissolute rabble which it was his misfortune to command; with whom all law was tyranny, and all order restraint" (II, 519-20). As a result of this textual ambivalence, Irving is forced in the nationalist text to account for the destructive power of "civilization" by redirecting his blame away from "the white men" (a phrase that indicts European civilization as a whole) toward Columbus' followers, that "dissolute rabble." Likewise, Irving attempted to dissociate Columbus from the "fiat" of the white men by isolating him in the rarefied atmosphere of conventional praise, and vituperating against his followers as slanderers, rapists and murderers who were driven by avarice, lust, superstition, bigotry and envy. Irving attempted, in other words, to account for his vision of civilization's destructive power by placing the responsibility for the consequences of that power not on the projector and policy-maker of the voyages of discovery but on his followers.

Irving repeatedly employs this strategy to extricate Columbus (and occasionally close associates like his brother) from situations that might otherwise have made them look like bloodthirsty conquerors. For example, Irving blames the defeat of the policies of the Adelantado, Columbus' brother, on the "excesses of worthless and turbulent men" and claims that if these few had not been so greedy, "a large revenue might have been collected, without any recourse to violence or oppression. In all instances, these simple people appear to have been extremely tractable, and meekly and even cheerfully to have resigned their rights to the white men, when treated with gentleness and humanity" (II, I58). And later in the same vein: "It seems almost incredible that so small a number of men, restrained too by well-meaning governors, could in so short a space of time have produced such widespread miseries. But the principles of evil have a fatal activity. With every exertion, the best of men can do but a moderate amount of good; but it seems in the power of the most contemptible individual to do incalculable mischief" (II, 204).

By adopting what was essentially a mythopoeic convention-pitting 
a good hero against evil antagonists (in this case, Columbus against his followers)-Irving had to employ a very awkward double standard. In the passages which vindicate Columbus and his brother, for example, Irving's attempt to throw all of the blame on the followers ignores the obvious connection between Columbus' policies and the eventual destruction of the island paradise. The notion that any human being could "cheerfully" resign his rights to the white men or that any conquest which involved the subjugation of an entire population could be "without oppression" is graphically inconsistent with Irving's description of the actual "benefits" of civilization as "avarice, and pride, and ambition, and pining care, and sordid labor, and withering poverty." Columbus was like his followers in seeing the natives as a resource to be exploited, and he differed from them only in the ways he thought that exploitation should be carried out (see, for example, II, 5I-59).

The most conspicuous example of Irving's use of a double standard to judge the behavior of Columbus is seen in his handling of the explorer's religious notions. In the nationalist text, Irving presented Columbus' religious "vision" as evidence of his enlightened genius and of his qualifications as a mythic hero. Columbus' primary ambition in life, according to Irving, was not the discovery of a new passage to the East or any other material goal but rather the accumulation of enough wealth to finance an extended crusade to Jerusalem in order to liberate the Holy Sepulchre from the power of the infidels (I, IоI). This ambition completely vindicated him: "It is essential to a full comprehension of the character and motives of Columbus, that this visionary project should be borne in recollection. ... It shows how much his mind was elevated above selfish and mercenary views-how it was filled with those devout and heroic schemes, which in the time of the crusades had inflamed the thoughts and directed the enterprises of the bravest warriors and the most illustrious princes" (I, 286).

In the anti-imperialist sub-text, however, Irving condemned the motives of other Christians involved in the crusades and dismissed their religious rhetoric as a mask behind which they exploited foreign peoples: "During the crusades, a doctrine had been established among Christian princes extremely favorable to ambitious designs. According to this, they had the right to invade, ravage, and seize upon the territories of all infidel nations, under the plea of defeating 
the enemies of Christ, and extending the sway of his church on earth" (I, 294). While Irving could not, in the sub-text, credit the avowed religious motives of the crusaders, he was forced, in the nationalist text, to deny any mercenary interests on Columbus' part in order to show that his hero's views were elevated above those of ordinary men. The accumulation of wealth was simply a means by which his cultural hero could attain one of his principal objects, which "was undoubtedly the propagation of the Christian faith" (I, II9).

By making such an artificial distinction between Columbus and other Europeans, Irving was forced to speculate about the benefits that would have accrued to mankind had the vision of Columbus been allowed to fulfill itself. Where he found nothing worthy of honor and glory in the results of his hero's conduct; where, on the contrary, he found that his hero had instituted the policy of repartimiento, by which the Spaniards first exploited the natives, and had advocated and begun the widespread enslavement of the Indians to be sold in the markets of Seville; and where he discovered that only twelve years after the discovery of Hispaniola by Columbus, "several hundred thousand of its native inhabitants had perished, miserable victims to the grasping avarice of the white men" (II, 458); where he found all this, Irving was reduced to praising Columbus for having thought that it might have been otherwise.

In spite of the eulogistic passages, therefore, it is difficult not to conclude that Columbus misunderstood and consequently destroyed the American Eden. His heroism and benign paternalism, his religious fervor and grand schemes for a new civilization appear, in the end, to be self-delusions which mask the same avarice, bigotry and ethnocentrism that characterized the lowest of his followers. The only difference between this Columbus and his followers is that he has more carefully developed rationalizations of his destructive and aggressive instincts. But such a portrait of Columbus, had Irving developed it explicitly, would have accorded poorly with the search for an American hero. It had to be denied in his nationalist commentary. Still, the presence in the text of so much anti-colonial sentiment seems to suggest that Irving was not able to repress completely his awareness of another, darker interpretation of his hero. By taking upon himself the role of national myth-maker, Irving seems also to have taken on the national bad conscience. 
It could be argued, of course, that Irving was aware of his ambivalence and that he purposely exploited it to create an ironic text, a subdued form of Knickerbocker's History of New York. But whereas he almost always speaks of his ironic intentions in other texts, either in the texts themselves or in his correspondence, his letters about Columbus all claim that it is a straightforward, serious attempt to write a nationalist biography. And indeed, if he was ironic, his intentions were entirely lost on his reviewers, all of whom read the book exactly as Irving claimed it had been written-as an attempt to "vindicate great names from . . . pernicious erudition."

Irving's difficulties with Columbus stemmed, however, from more than a conflict between the demands of literary nationalism and the reality of colonialism. A consistent portrait of Columbus was further hampered by the incompatibility of Irving's nationalist hero-worship and a deeper, more complex conception of Columbus' character that was based in Irving's fiction rather than in any previous models of Columbus in the biographical tradition. On the one hand, Irving saw Columbus as the first type of the new "American" man: practical, scientific, and empirical. On the other hand, Irving saw a national hero who was gifted with a peculiarly strong imagination. As a man with poetic and visionary powers, whose task it was to "name" the New World, Columbus represented the first test of the European imagination in the Americas. He was, in a sense, the prototype of the American artist whose creative sources were still in the Old World.

Like the nationalist aspect of the biography, the combination of the practical and the imaginative in Irving's Columbus is best understood when viewed within the context of the culture in which it was created. Terence Martin, in his highly useful study "Rip, Ichabod, and the American Imagination," 10 argues that American society in Irving's day had adopted the attitude, prevalent among English literary theorists, that "poetry and art belong properly to primitive, that is culturally childish, societies" and concludes that Americans, in

${ }^{9}$ For a discussion of the changes which occurred in Irving's attitudes toward America and his embarrassment over the Knickerbocker satire, see Robert A. Ferguson, "Hunting Down a Nation': Irving's $A$ History of New York," Nineteenth-Century Fiction, 36 (1981), $4 \mathrm{I}-46$.

${ }^{10}$ American Literature, 31 (1959), 137-49. For a contemporary discussion of this issue, see Alexis de Tocqueville, Democracy in America, ed. R. N. Heffner (New York: New American Library, 1956), pp. 169-78. 
their "desire for immediate adulthood," had developed "a pervading mistrust of the imagination."

Martin's reading of "the Legend of Sleepy Hollow" and "Rip Van Winkle" in this context of "pervading mistrust" is very illuminating. Ichabod and Rip are given to indolence, imaginative indulgence, and superstitution, all qualities which in Irving's view were necessary to the imaginative writer. Both are defeated finally by the " 'busy, bustling, disputatious' self-consciously adult United States of America." Martin draws from this analysis the conclusion that "Irving's most characteristic fiction involves variations on the basic pattern of victory for the practical and defeat for the impractical and visionary," and he seems to suggest that the pattern reflects Irving's mixed emotions about his own role as a writer in America. In these stories, Irving indicted America for its lack of culture, but he also expressed approval for the hardy, no-nonsense practicality of the new society which saw artists as useless, though harmless, visionaries.

These observations are apt and apply well to Irving's fiction, but when Martin attempts to analyze Columbus, he too readily accepts a distinction between fiction and non-fiction ("Irving could not historicize Rip and Ichabod nor could he fictionalize Christopher Columbus") and assumes that the historical hero is an image "of exactly what made America what it wanted to be." Like those critics who perceive in Irving's Columbus only the mythic cultural hero, Martin sees only a hero "who meets the challenges of the unknown rationally and scientifically" and who exemplifies the American truism that "science, ingenuity, and reason have triumphed over superstition, fear, and fancy."

Assuming that the historical Columbus could not be fictionalized overlooks the fact that Irving describes his hero repeatedly in precisely the same terms which characterized Ichabod. Like his fictional character, Irving's Columbus was the continual victim of delusions, his conclusions about the New World were a "riot of the imagination" (I, I86), his descriptions of the landscape and wildlife were "deceived" (I, 184$)$ and were a "tissue of errors and misconceptions" (I, I88), and he had "the deep tinge of superstition" (II, 396). Both those who see Columbus as a nationalist eulogy and those who see it as a paean to the triumph of science over superstition ignore the tragedy which the discovery of the Americas caused, both for the native populations and for Columbus himself. Throughout the book, 
Irving reminds the reader that the New World was "devoted" from the moment the Europeans arrived and that the suffering which Columbus endured on account of his discoveries beclouded "his declining years with humiliation and disappointment" (I, 236). By ignoring the impractical and visionary side of Columbus, as well as the horrors of European colonization, such readings of the biography fail to see in Irving's attempt to establish a mythic American history the same ambivalence that Martin so carefully points out in Irving's fiction.

The visionary and superstitious side of Columbus, which echoes the superstition of Rip and Ichabod, has its literary roots in Cervantes' portrait of Don Quixote, a fact which critics have usually overlooked. ${ }^{11}$ According to Irving, Columbus had become so imbued with the writings of Marco Polo, and was so convinced that the regions toward which he sailed were those traversed by the earlier traveler, that his perceptions were a mixture of fiction and reality. Marco Polo's narratives, says Irving, “are thus particularly noted, from the influence they had over the imagination of Columbus. The work of Marco Polo is a key to many parts of his history" (I, 60). This delusion becomes a recurrent and important theme. Later, Irving remarks that "it is curious to observe how ingeniously the imagination of Columbus deceived him at every step, and how he wove every thing into a uniform web of false conclusions" (I, 190), and "such was the singular nature of this voyage, a continual series of golden dreams, and all interpreted by the deluding volume of Marco Polo" (I, I9I). When Columbus begins the search for gold in Hispaniola, the "fancied traces of ancient excavations gave rise to one of his usual veins of golden conjectures. He had already surmised that Hispaniola might be the ancient Ophir. He now flattered himself that he had discovered the identical mines, whence King Solomon had procured his gold for the building of the temple of Jerusalem“ (II, 79). Like Cervantes' Don, as well as Irving's own Ichabod Crane, Columbus is deluded about the nature of reality because of an obsession with literature. In Columbus' case, the obsession is with the

11 The one exception is Hedges, whose article (pp. 134-39) argues that the quixotic element was Irving's real contribution to the Columbus characterization. Hedges goes so far as to suggest that Columbus prefigures the "diabolic" Ahab, a suggestion that supports my argument that Irving's characterization is an ambivalent one. Hedges' essay is by far the best that I have found on Irving's Columbus. 
volumes of Marco Polo, Don Quixote was entranced by chivalric romances, and Ichabod "firmly and potently believed" in Cotton Mather's History of Witchcraft, a New England Almanac.

Irving used Columbus' quixotic delusions about New World geography, as he had his religious "vision," to dissociate the hero from any intentional wrong-doing, but this is an obvious and clumsy attempt to fit together two wholly different approaches to the character. The heroic Columbus may be dissociated from his followers on the basis of his "goodness" (as he is in the nationalist text), but by dissociating him on the basis of his superstition and delusions, Irving undermines his heroic status and raises the possibility of a direct relationship between Columbus' misconcèptions and the destruction of the earthly paradise. Irving borrowed from his fictional characters partly because their kind of deluded innocence might serve to exonerate Columbus, but in doing so he had forgotten that the New World Quixote differs from these literary models in a very important way: whereas the latter's delusions were essentially harmless, the former's were backed up by the immense power of the Spanish monarchy. This difference is obvious and unavoidable in the subtext, but the threat it posed to the mythic Columbus required that it be overlooked and that Columbus' power to do evil be repressed.

In spite of the similarities between Irving's fictional characters and Columbus, their ambivalent treatment is more formally controlled in the fiction than in the biography. In the fictional characters, the two types of traits-imagination and practicality-are split between the comic heroes, who possess the former, and their adversaries (like Brom Bones), who possess the latter. Since Irving shows sympathy for both sides-Rip and Ichabod are childish and easily duped but likeable, their adversaries are prosaic but they get things done-his ambivalence in the fictional work appears to be the result of a conscious effort to create a comic resolution to the problems facing the imaginative artist in America. In Columbus, on the other hand, the hero himself contains both types of traits. Columbus had "a character richly compounded of extraordinary and apparently contradictory elements" (II, 397). Like Ichabod Crane, he is visionary and superstitious; and like the materialistic enterprisers of post-Revolutionary America, he is also, as Martin says, practical and scientific. The struggle between two visions of America is, therefore, initially present in Columbus' own character, and Irving, borrowing themes from 
his fictional work, seems to have been aware of this. But in his effort to mythicize Columbus, he shortcircuits the development of this struggle by externalizing the conflict and transforming it into a battle between an ineffectual "goodness" (Columbus and his brother) and a powerful "evil" (the avaricious white man). The moral ambiguities of the internal conflict between different sides of Columbus' character are, in other words, subverted by the moral absolutes of literary nationalism's need for heroes. The result is that the designed ambivalence of the fiction becomes in Columbus a real ambivalence. The author's need to exonerate his hero conflicts with, and ultimately subverts, his exploration of alternative visions of America.

In the context of the struggle for a national literature, Irving's attempts to manipulate his portrait of Columbus reveal vividly not only the infant country's need to transform historical reality into wish-fulfilling myths but also the peculiar way in which this struggle expressed the author's search for an identity in the new world. Students of autobiography have long been aware of the relationship between emerging group consciousness and the development of individual identity. Robert Sayre, for example, has argued that "in the early nineteenth century, autobiography united the struggle to develop an indigenous literature with the even more fundamental motive to define and create an American character. The tacit second question after Crevecoeur's 'What then is an American?' is, 'and who am I?" "12 Sayre, however, does not mention in his catalogue of autobiographical forms which answered these questions either the history or the biography, both of which were used extensively to provide a definition of national character. In the cultural situation in which Irving wrote, the re-creation of national history was, to a large extent, a necessary extension of the individual's identity and history. And biography, which attempted to create national heroes, was even more specifically directed toward the creation and definition of an American character.

One should be careful, however, not to make too facile a connection between literary nationalism and Irving's portrait of Columbus. The book, after all, was written not by a committee of patriots but by an individual who had developed his writing talents as a satirist

12 "The Proper Study-Autobiography in American Studies," American Quarterly, 29 (Bibliography Issue, 1977), 241-62. 
of the American past. What one can see in Columbus is Irving's struggle to define his own American identity by defining the nature of an American hero. As an offering to his country of "so interesting and national a kind" ( $\mathrm{I}, \mathrm{I0})$, Columbus was a down-payment on Irving's reinvestment in national pride toward the end of his long sojourn in Europe.

The significance of Irving's Columbus, therefore, lies not in its transformation of the ambiguous past into the moral absolutes of a national mythology (there were plenty of hack-writing patriots around to perform this mechanical task), but in the complexities that developed out of the conflict between Irving's internalization of the national mythology and his obtrusive skepticism about America's past and his own role in society. ${ }^{13}$ In fact, Irving was so far from succeeding as a national mythologizer that even if one granted his success in conferring upon Columbus a heroic status, his version of the American past was still compromised by the genocidal nature of European colonialism. But Irving did not succeed entirely even in his limited endeavor to exonerate Columbus, for the discoverer himself is implicated in the genocide. One reason for the biography's lack of lasting popularity may be that, because of its ambivalence about America, it satisfies neither patriotic Americans, who must feel extremely uncomfortable with the sanguinary nature of the colonial project, nor cynics, who are irritated by the florid eulogistic passages.

Irving's identification with the fortunes of the young republic committed him to a portrait of Columbus consistent with the needs of literary nationalism. But his ambivalence about his role in the new country seems to have made of Columbus an odd mixture of heroworship and hero-deflation. By fashioning Columbus, in part, according to the mold that had created Ichabod Crane, Irving used him, as he had his fictional characters, as a means to define the role of the imagination in America. The defeat of Columbus' grand schemes and ultimately the destruction of his vision of America are

\footnotetext{
13 While a detailed discussion is beyond the scope of the present essay, I would suggest that this conflict and the ambivalence it engendered may also be seen in Irving's history of the Northwest fur trade Astoria (1836) in which John Jacob Astor becomes a kind of Columbian figure. Even more interestingly, the conflict arises again in Irving's autobiographical $A$ Tour on the Prairies (1835). In this travel narrative, he attempts to find his place within the national myth that the American wilderness would transform "effeminate" Europeans into heroic manly types. Once again, however, the conflict between myth and reality is treated ambivalently rather than explicitly.
} 
a direct reflection of Irving's pessimism about the effectuality and stability of a spiritual or literary imagination in a practical and acquisitive world. Considering the low regard in which artists were held in his own day this defeat must have been charged with significance for the biographer. Like Columbus, the literary artist in the early nineteenth century could be used to justify the accumulation of wealth, but he was otherwise dismissed as childish and impractical. 
Copyright of American Literature is the property of Duke University Press and its content may not be copied or emailed to multiple sites or posted to a listserv without the copyright holder's express written permission.

However, users may print, download, or email articles for individual use. 